\title{
Marital Satisfaction: The Differential Impact of Social Support Dependent on Situation and Gender in Medical Staff in Iran
}

\author{
Arian Rostami ${ }^{1}$, Mehdi Ghazinour ${ }^{1} \&$ Jörg Richter ${ }^{2}$ \\ ${ }^{1}$ Department of Social Work, Umeå University, Umeå, Sweden \\ ${ }^{2}$ Centre for Child and Adolescent Mental Health, Oslo, Norway \\ Correspondence: Arian Rostami, Department of Social Work, Umeå University, Sweden. E-mail: \\ arian.rostami@gmail.com
}

Received: April 4, 2013 Accepted: April 18, 2013 Online Published: May 12, 2013

doi:10.5539/gjhs.v5n4p151 URL: http://dx.doi.org/10.5539/gjhs.v5n4p151

This study was financially supported by Tehran University of Medical Sciences

\begin{abstract}
Stress is unavoidable in everyday life and it can effect on marital relationship. Social support especially from emotionally closed persons as a protective factor can help individuals to deal with stress and buffers the negative effects of life stress on marital satisfaction. In the present cross-sectional study we investigated the relationship between social and spousal support and marital satisfaction in medical staff in Iran. Data collection was performed in 653 medical staff using socio-demographic questions, the ENRICH Marital Satisfaction Inventory, and the Social Support Questionnaire. Women and men did not differ in total social support satisfaction and the total number of supporting people; but, women were more often support providers for their husbands than men were for their wives. Spouse support was a more important indicator of marital satisfaction for women than for men. Also results revealed that spouse support is more important than social support from other resources to explain marital satisfaction. Job satisfaction had an explanatory effect on marital satisfaction especially in men. Furthermore, the findings showed that social support could decrease the explanatory impact of job satisfaction on scales of marital satisfaction. Therefore, focusing on social support, especially spouse support could be an effective approach in family counseling or family education programs to improve marital satisfaction in medical staff.
\end{abstract}

Keywords: marital satisfaction, social support, job satisfaction, medical staff, Iran

\section{Introduction}

Acute and chronic stressful experiences significantly influence the development of close relationships and marital satisfaction (Neff \& Karney, 2004, 2005; Story \& Bradbury, 2004). The effect of stress on marital relationship can be in three ways; negative effect on couple's communication, decrease in time spend together, and increase in health problems. Stress protective factors can emerge from within individuals (e.g., coping, resilience), couples (e.g. marital communication) and outside family contexts (Patterson, 2002). Social support as a protective factor has effect in face of psychosocial stress (stress, social support and the buffering hypothesis). Particularly support from emotionally close persons can provide psychological resources needed to cope with stress (Cohen, 2004) and buffer negative effects of life stress on marital satisfaction (Chi et al., 2011). Social support refers to the function and quality of social relationships which can be as perceived support or actual received support (Sarason, Levine, Basham, \& Sarason, 1983; Schwarzer \& Leppin, 1991). Perceived social support has been defined as "an individual's perceptions of general support or specific supportive behaviors (available or enacted on) from people in their social network, which enhances their functioning or may buffer them from adverse outcomes" (Demaray \& Malecki, 2002).

Social support includes providing instrumental support (actual help in time, money, and energy), informational support (information, suggestion and advice), appraisal support (evaluative feedback) and emotional support (empathy, trust, caring and love) (House, 1981). Women often have a greater number of close relationships and also a more extensive social network than men (Laireiter \& Baumann, 1992; McFarlane, Neale, Norman, Roy, \& Streiner, 1981). Additionally, women provide more emotional support to others; and they seek and receive more 
social support (Ashton \& Fuehrer, 1993; Klauer \& Winkeler, 2002; Reevy, 2007). Also, they benefit from the stress-buffering effects of social support more than men (Bellman, Forster, Still, \& Cooper, 2003). Women emphasize intimacy and self-disclosure in their close relationships, and they are more empathetic, expressive, and disclosing than men.

Social support is one of the most important factors in marital relationships (Acitelli, 1996; Gottlieb, 1994). Studies found positive associations between satisfaction with spousal support and marital satisfaction (Acitelli, 1996; Julien \& Markman, 1991; Pasch \& Bradbury, 1998). Spouses expect partners to "be there" for help to solve problems, as well as providing consolation when problems lack solutions. Although both husbands and wives do turn to others in their social networks for various types of support, spouses remain an important source of support (Beach, Martin, Blum, \& Roman, 1993; Walen \& Lachman, 2000). Indeed, findings supported that social support from sources outside the marriage cannot compensate the lack of spousal support (Coyne \& Delongis, 1986; Lieberman, 1982). Belle (1982) hypothesized that women provide more support than they receive in their marital relationship. Some studies also suggest that men and women differ in their perceptions of spouses' support. Vinokur and Vinokur-Kaplan (1990) and Vanfossen (1981) found that husbands rate their spouses more supportive than did wives. In contrast, some other studies yielded results inconsistent with the support gap hypothesis. They revealed that men and women often report that they received similar types and amounts of support from partners (DeLongis, Capreol, Holtzman, O'Brien, \& Campbell, 2004; Neff \& Karney, 2005).

Medical staff faces many stressors in their job. Patients' pain and suffering, work time pressure, heavy workload, inadequate salary, and inequality at work are perceived as major sources of stress by hospital employees (Adeb-Saeedi, 2002; Cory, 2007; Mosadeghrad, Ferlie, \& Rosenberg, 2011; Roberts \& Levenson, 2001). Studies indicated that job stress can affect negatively on individuals' quality of life, but also on their marital relationship (Ardekani, Kakooei, Ayattollahi, Choobineh, \& Seraji, 2008; Bodenmann, 2000; Hamaideh, 2012; Mauno \& Kinnunen, 1999; Serafini, 2010; Su, Weng, Tsang, \& Wu, 2009; Wu, Li, Wang, Yang, \& Qiu, 2011). Job dissatisfaction or being employed in a high demanding job as an everyday stress can negatively influence individual's wellbeing, quality of relationships and marital satisfaction (R. Hill, 1958; Hochschild, 1997; D. Hughes, Galinsky, \& Morris, 1992; D. L. Hughes \& Galinsky, 1994; Rogers \& May, 2003). Job, family and individual characteristics stressors (for example; job pressure, job hours, and household duty) as A (stressors) in the ABCX model (R. Hill, 1958; McCubbin \& Patterson, 1983) in family stress theory and work, family, individual characteristics resources and support as B (recourses and support) results the perception of work-family conflict and facilitation as corresponding to C. Theoretically, interactions of these three lead to outcome (X). In this model job satisfaction is identified as work outcomes; family satisfaction and marital satisfaction as family outcomes; and life satisfaction and individual stress as individual outcome (Hill, 2005). Then, based on this model social support as a moderator can improve physical and psychological health, facilitate couples' marital satisfaction and job satisfaction in medical staff that are under the pressure of job stress (Aycan \& Eskin, 2005; Button, 2008).

In the present study, we investigated the relationship between social and spousal support and marital satisfaction in medical staff in Iran. The objective of our study was to analyse: 1) social and spousal support in different situations among medical staff; 2) gender differences in social and spousal support; 3) associations between social and spousal support and marital satisfaction by gender; and (d) The moderator effect of socio-demographic variables, job satisfaction and social and spousal support dependent on the domains of marital satisfaction.

\section{Material and Methods}

\subsection{Sample and Procedure}

This was a cross-sectional study on social and spouse support and marital satisfaction in 653 medical staff in hospitals that are affiliated to Tehran Medical University. The sample comprised of married (for at least one year) medical staff, who lived together with their spouse; who did not had any addiction problems or severe physical and psychological disorders which could affect their life (see Table 1 for characteristics of the sample). 
Table 1. Socio-demographic variables by gender

\begin{tabular}{|c|c|c|c|c|c|}
\hline & Females & Males & $\mathrm{t}$ & Df & $\mathrm{p}$ \\
\hline $\mathrm{N}$ & 477 & 175 & & & \\
\hline Years married & $9.29 \pm 7.19$ & $10.74 \pm 7.52$ & -2.20 & 298 & .028 \\
\hline Age & $35.36 \pm 7.14$ & $39.22 \pm 7.70$ & -5.79 & 291 & $<.001$ \\
\hline Number of children & $0.97 \pm 0.97$ & $1.31 \pm 0.95$ & -4.09 & 650 & $<.001$ \\
\hline Spouse's age & $38.13 \pm 8.25$ & $34.68 \pm 6.95$ & 5.33 & 365 & $<.001$ \\
\hline Job-Satisfaction & $2.91 \pm 0.92$ & $3.16 \pm 1.19$ & -2.54 & 255 & .012 \\
\hline Number of Children & $0.99 \pm 0.93$ & $1.26 \pm 1.07$ & & & \\
\hline \multicolumn{6}{|c|}{ Education of the subject $(\mathrm{N})$} \\
\hline HND & $102(21.4 \%)$ & $57(32-6 \%)$ & \multirow{3}{*}{$\begin{array}{l}\chi^{2} \\
26.44\end{array}$} & & \\
\hline Bachelor & $317(66.5 \%)$ & $78(44.5 \%)$ & & & $<0,001$ \\
\hline Master or higher & $58(12.2 \%)$ & $40(22.9 \%)$ & & & $<0.001$ \\
\hline \multicolumn{6}{|c|}{ Education of the spouse } \\
\hline HND & $194(40.7 \%)$ & $62(35.4 \%)$ & \multirow{3}{*}{$\begin{array}{l}\chi^{2} \\
2.87\end{array}$} & & \\
\hline Bachelor & $199(41.7 \%)$ & $86(49.1 \%)$ & & & 0230 \\
\hline Master or higher & $84(17.6 \%)$ & $27(15.4 \%)$ & & & 0.238 \\
\hline \multicolumn{6}{|c|}{ Employment of the spouse } \\
\hline Employed & $447(93.7 \%)$ & $101(57.7 \%)$ & $\chi^{2}$ & & \\
\hline Not employed & $30(6.3 \%)$ & $74(42.3 \%)$ & 123.74 & & $<0.001$ \\
\hline
\end{tabular}

HND: Higher National Diploma

The study was approved by the scientific and Ethics committee of Tehran Medical University, Iran. After receiving the permission to perform the investigation from the Tehran Medical University and hospital managers, the aims of study were explained to the staff of every hospital ward by the principle researcher. Participants were asked to complete a set of questionnaires. Participation in the study was voluntary; and the participants could withdraw from the investigation at any time of the investigation.

\subsection{Instruments}

Data was collected by a set of questionnaire which was split into three parts; a socio-demographic form, the ENRICH marital satisfaction inventory, and the Social Support Questionnaire (SSQ).

The Socio-demographic questionnaire was designed by the principal researcher to collect socio-demographic information such as participant's age, gender, education, length of marriage, number of children, spouse's age, education, job satisfaction (single, general question to be answered on a 5-point scale between 1 very dissatisfied and 5 very satisfied) and some other socio-demographic variables.

The ENRICH Marital Satisfaction inventory (Evaluating \& Nurturing Relationship Issues, Communication, and Happiness) is a multidimensional self-report measurement of marital satisfaction that was developed by Olson and colleagues (Olson, Fournier, \& Druckman, 1983). It includes 125 items to be answered on a 5-point Likert scale ranging from very dissatisfied to very satisfied) grouped into 14 domains; Idealistic Distortion, Marital Satisfaction, Personality Issues, Communication, Conflict Resolution, Financial Management, Leisure Activities, Sexual Relationship, Children and Parenting, Family and Friends, Equalitarian Roles, Religious Orientation, Marital Cohesion and Marital Change (Fowers \& Olson, 1989). The short form of this questionnaire that was standardized by Soleimanian (1994) was applied for assessing marital satisfaction in the present study. This version consists of 47 items in 9 scales: personality issues, marital communication, conflict resolution, financial management, pleasure activities, sexual activities, marriage and children, family and friends, and religious orientation. Construct validity by comparison with a Family Satisfaction Scale showed an acceptable level of shared variance (0.41-0.60) between the scales. Internal consistency for the measure was calculated as Cronbach's alpha of 0.95 for men and women. Furthermore test-retest reliability was measured with a reliability 
coefficient of 0.92 (Rasooli, 2001).

The Social Support Questionnaire (SSQ) (Sarason et al., 1983) is a self-report questionnaire consisting of 27 scenarios. In relation to each scenario, respondents are asked: (a) to report any persons who would be accessible for support in that circumstance and (b) how satisfied they would be with the available support for that specific situation on a 6-point Likert scale ranging from 1 (very dissatisfied) to 6 (very satisfied). Based on the responses to the two questions two scores are originally calculated: the average number of available supportive individuals (Social Support Questionnaire Number-SSQN) and the average satisfaction with the available SS (Social Support Questionnaire satisfaction-SSQS). The validity and reliability of the Persian version of the SSQ was satisfactory (SSQN $\alpha=0.95$ and SSQS $\alpha=0.96$ ) (Nasseh, Ghazinour, Joghataei, Nojomi, \& Richter, 2011). We additionally created a third scale representing the frequency of reporting the spouse as a supporting person. Furthermore, the scenarios of the SSQ were grouped for this study according to the type of situation by expert ratings (six clinical psychologists and social workers). Six domains were derived: Need for self-disclosure (scenarios 1, 6, 11, 14, 21); Need for support in loss situations (scenarios 2, 4, 10, 18); Need for belonging (scenarios 3, 20, 24); Need for instrumental support (scenarios 5, 8, 9, 13, 26); Need to be praised (scenarios 7 , $12,19,22$ ); and Need for emotional support (scenarios 15, 16, 17, 23, 25, 27). The average number of supporting persons, the average satisfaction with the support and the average frequency of reporting the spouse as a supporting person were computed for each of the domains.

\subsection{Statistical Analysis}

Descriptives of the assessed variables are reported in terms of mean scores and standard deviations or percentages dependent on the scale level by gender. T-test was used for testing for group differences for continuous variables and $\chi^{2}$-test for categorical variables. Pearson correlation coefficients are provided to indicate associations between continuous variables. Hierarchical multiple regression analysis was used to test for the predictive value of socio-demographic variables in a first block (method: enter) and social support related variables in a second block (method: stepwise) with marital satisfaction domains as dependent variables. All the calculations were run by gender. The analysis was performed by SPSS 19 for PC and Mac.

\section{Results}

\subsection{Marital Satisfaction}

Male medical staff members reported an overall significant higher marital satisfaction than the females mainly based on that they were more satisfied in the domains of personality issues, conflict resolution, sexual activities, family and friends, marital communication and Marriage and Children (Table 2).

Table 2. Marital satisfaction domains by gender

\begin{tabular}{llllll}
\hline & Females & Males & $\mathrm{t}$ & $\mathrm{df}$ & $\mathrm{p}$ \\
\hline Personality Issues & $16.75 \pm 4.45$ & $18.18 \pm 4.43$ & -3.65 & 650 & $<.001$ \\
Marital Communication & $17.16 \pm 4.42$ & $17.98 \pm 4.32$ & -2.10 & 650 & .036 \\
Conflict Resolution & $17.07 \pm 4.01$ & $18.15 \pm 3.41$ & -3.42 & 361 & .001 \\
Financial Management & $18.14 \pm 4.17$ & $18.64 \pm 3.25$ & -1.64 & 395 & .102 \\
Pleasure Activities & $17.67 \pm 3.53$ & $17.79 \pm 3.61$ & -0.39 & 650 & .698 \\
Sexual Activities & $17.61 \pm 3.69$ & $18.71 \pm 3.30$ & -3.44 & 650 & .001 \\
Marriage \& Children & $17.21 \pm 3.82$ & $18.10 \pm 4.43$ & -2.08 & 426 & .038 \\
Family \& Friends & $17.02 \pm 3.36$ & $17.77 \pm 3.44$ & -2.50 & 650 & .013 \\
Religious Orientation & $18.61 \pm 3.98$ & $18.99 \pm 3.76$ & -1.07 & 650 & .285 \\
Marital Satisfaction Total & $158.54 \pm 27.37$ & $166.71 \pm 26.82$ & -3.40 & 650 & .001 \\
\hline
\end{tabular}

\subsection{Social Support}

Neither the average total number of supporting persons, nor the average total satisfaction with perceived social support differed between the genders. However, men reported significantly more often their wives as supporting persons than women named their husbands as supporting. 
Table 3. Social support domains by gender

\begin{tabular}{|c|c|c|c|c|c|}
\hline & Females & Males & $\mathrm{t}$ & df & $\mathrm{p}$ \\
\hline Total Social Support Number & $2.01 \pm 1.11$ & $1.94 \pm 1.09$ & 0.69 & 650 & .493 \\
\hline Total Social Support Satisfaction & $4.81 \pm 1.07$ & $4.66 \pm 1.30$ & 1.50 & 650 & .133 \\
\hline Spouse Support Total & $15.56 \pm 8.34$ & $17.85 \pm 6.88$ & -3.45 & 352 & .001 \\
\hline Need for Self-Disclosure Number & $2.03 \pm 1.11$ & $2.17 \pm 1.23$ & -1.34 & 639 & .181 \\
\hline Self-Disclosure Satisfaction & $4.87 \pm 0.96$ & $4.94 \pm 0.95$ & -0.86 & 639 & .389 \\
\hline Self-Disclosure Spouse & $0.58 \pm 0.32$ & $0.67 \pm 0.29$ & -3.45 & 639 & .001 \\
\hline Support in Loss Situations Number & $1.54 \pm 1.33$ & $1.46 \pm 1.30$ & 0.64 & 639 & .521 \\
\hline Loss Situations Satisfaction & $4.46 \pm 1.26$ & $4.04 \pm 1.24$ & 3.67 & 639 & $<.001$ \\
\hline Loss Situations Spouse & $0.35 \pm 0.29$ & $0.31 \pm 0.29$ & 1.45 & 639 & .148 \\
\hline Need for Belongingness Number & $2.82 \pm 1.51$ & $2.92 \pm 1.66$ & -0.67 & 271 & .501 \\
\hline Belongingness Satisfaction & $5.10 \pm 0.90$ & $5.27 \pm 0.83$ & -2.19 & 313 & .029 \\
\hline Belongingness Spouse & $0.70 \pm 0.35$ & $0.82 \pm 0.32$ & -4.29 & 324 & $<.001$ \\
\hline Need for Instrumental Support Number & $2.06 \pm 1.17$ & $1.98 \pm 1.10$ & 0.74 & 639 & .458 \\
\hline Instrumental Support Satisfaction & $4.99 \pm 0.95$ & $4.90 \pm 1.06$ & 1.06 & 639 & .291 \\
\hline Instrumental Support Spouse & $0.60 \pm 0.37$ & $0.67 \pm 0.34$ & -2.12 & 322 & .035 \\
\hline Need to be Praised Number & $2.02 \pm 1.24$ & $1.86 \pm 1.07$ & 1.49 & 639 & .137 \\
\hline Be Praised Satisfaction & $4.87 \pm 1.06$ & $4.82 \pm 1.21$ & 0.52 & 264 & .603 \\
\hline Be Praised Spouse & $0.56 \pm 0.36$ & $0.66 \pm 0.33$ & -2.98 & 639 & .003 \\
\hline Need for Emotional Support Number & $1.83 \pm 1.20$ & $1.77 \pm 1.08$ & 0.55 & 639 & .582 \\
\hline Emotional Support Satisfaction & $3.89 \pm 0.90$ & $3.95 \pm 0.86$ & -.879 & 639 & .385 \\
\hline Emotional Support Spouse & $0.50 \pm 0.31$ & $0.60 \pm 0.25$ & -4.22 & 363 & $<.001$ \\
\hline
\end{tabular}

Furthermore, men reported their wives as supporting persons significantly more often than women in scenarios related to need for belongingness, need for emotional support, need for self-disclosure, need to be praised, and need for instrumental support, and they evaluated their satisfaction with social support related to needs for belongingness substantially higher than the women. Women evaluated their satisfaction with social support in loss situations higher than the men (Table 3).

\subsection{Associations between Marital Satisfaction Domains and Social Support Domains}

The correlation between the average number of supporting persons and reporting the partner as supporting were of moderate to large effect size among the females staff with an average coefficient $r=0.47$ (ranging from needs for instrumental support $r=0.42$ to $r=0.52$ for scenarios related to needs for emotional support) and of small to moderate effect size among males $r=0.32$ (ranging from needs for emotional support $r=0.16$ to $r=0.35$ for scenarios related to needs to be praised) with a significant gender difference $(p=0.045)$. There was no difference between the average correlation between satisfaction with social support and naming the partner as supporting person which were of moderate to high effect size (women: $r=0.52$ - ranging from needs in loss situations $r=$ 0.49 to $r=0.59$ for scenarios related to needs for emotional support; men: $r=0.49$ - ranging from needs in loss situations $\mathrm{r}=0.37$ to $\mathrm{r}=0.59$ for scenarios related to needs to be praised).

\subsection{Prediction of Marital Satisfaction based on Social Support}

In hierarchical regression analyses by gender (Tables $4 a, b)$ with the various marital satisfaction domain scores as dependent variables and socio-demographic variables of impact (age, spouse's age, years married, subject's and partner's education, job and job satisfaction) included in the first block (method: enter) and the average number of supporting persons, the average satisfaction with social support, and the average frequency of reporting the partner as a source of support related to the six scenario-groups derived from the SSQ in the second block (method: stepwise) as independent variables a more differentiated pattern appeared: 
a) the variance of the socio-demographic variables from block 1 explained between $3 \%$ of the variance in Marriage \& Children and $16 \%$ in Financial Management among the female medical staff; and between $2 \%$ in Conflict Resolution and $20 \%$ in Marriage \& Children in the male staff;

b) the variance of the variables from block 2 (varying number and varying variables related to social support) additionally explained between $8 \%$ of the variance in Family and Friends and $28 \%$ in Conflict Resolution among the females and between $20 \%$ in Pleasure Activities and $37 \%$ in Marriage \& Children among the males;

c) the total amount of variance explained by both blocks together varied between $13 \%$ in Marriage \& Children and $37 \%$ in Personality issues for females and between $31 \%$ in Personality Issues and in Marital Communication and $57 \%$ in Marriage \& Children for males;

d) for the males, only $41.5 \%$ of the significantly contributing variables remaining in the regression equation were related to spouse support, whereas these were $66.7 \%$ for the women; and

e) social support from the husband in situations characterized by need for instrumental support and by need for self-disclosure was most often of predictive impact related to marital satisfaction among the females, whereas support by their wife in situations of needs for belongingness was most often of predictive impact among the males.

Table 4a. Hierarchical multiple regressions with social support domain scores as independent and marital satisfaction domains as dependent variables controlling for socio-demographic variables (Block 1) $\left(1^{\text {st }}\right.$ block: method enter; $2^{\text {nd }}$ block: method stepwise) in females

\begin{tabular}{|c|c|c|c|c|}
\hline Independent & Adjusted $\mathrm{r}^{2}$ & $\mathrm{~F}$ & $\mathrm{p}$ & Variables with significant standardized Beta $(\beta, \mathrm{t}, \mathrm{p})$ \\
\hline \multicolumn{5}{|c|}{ Personality Issues } \\
\hline Block 1 & 0.10 & & $<0.001$ & \\
\hline Block 2 & 0.37 & 31.85 & $<0.001$ & $\begin{array}{l}\text { Instrumental spouse }(0.36 ; 6.10 ;<0.001) \text {; belongingness spouse }(0.22 \text {; } \\
3.77 ;<0.001)\end{array}$ \\
\hline \multicolumn{5}{|c|}{ Marital Communication } \\
\hline Block 1 & 0.14 & & $<0.001$ & \\
\hline Block 2 & 0.36 & 30.30 & $<0.001$ & $\begin{array}{l}\text { Instrumental spouse }(0.28 ; 4.76 ;<0.001) \text {; belongingness spouse }(0.24 \text {; } \\
4.03 ;<0.001) \text {; }\end{array}$ \\
\hline \multicolumn{5}{|c|}{ Conflict Resolution } \\
\hline Block 1 & 0.06 & & $<0.001$ & \\
\hline Block 2 & 0.34 & 27.84 & $<0.001$ & $\begin{array}{l}\text { Belongingness spouse }(0.39 ; 6.79 ;<0.001) \text {; praise spouse }(0.19 ; 3.24 \text {; } \\
0.001)\end{array}$ \\
\hline \multicolumn{5}{|c|}{ Financial Management } \\
\hline Block 1 & 0.16 & & $<0.001$ & \\
\hline Block 2 & 0.36 & 30.30 & $<0.001$ & $\begin{array}{l}\text { Instrumental spouse }(0.34 ; 5.76 ;<0.001) \text {; belongingness spouse }(0.15 \text {; } \\
2.62 ; 0.009)\end{array}$ \\
\hline \multicolumn{5}{|c|}{ Pleasure Activities } \\
\hline Block 1 & 0.06 & & $<0.001$ & \\
\hline Block 2 & 0.23 & 13.65 & $<0.001$ & $\begin{array}{l}\text { Emotional spouse }(0.35 ; 6.59 ;<0.001) \text {; instrumental no. }(-0.25 ;-3.57 \text {; } \\
<0.001) \text {; praise no. }(0.21 ; 2.95 ; 0.003) \text {; praise satisfaction }(0.12 ; 2.26 \text {; } \\
0.024)\end{array}$ \\
\hline
\end{tabular}

\section{Sexual Activities}

Block $1 \quad 0.07$

Block $2 \quad 0.22$

$<0.001$

Belongingness spouse $(0.26 ; 4.208 ;<0.001)$; praise spouse $(0.16 ; 2.541$; 0.012);

\begin{tabular}{|c|c|c|c|c|}
\hline \multicolumn{5}{|c|}{ Marriage and Children } \\
\hline Block 1 & 0.03 & & 0.039 & \\
\hline Block 2 & 0.13 & 6.02 & $<0.001$ & Praise spouse $(0.18 ; 2.03 ; 0.043)$; instrumental spouse $(-0.19 ; 2.09 ; 0.037)$ \\
\hline
\end{tabular}




\begin{tabular}{|c|c|c|c|c|}
\hline Independent & Adjusted $\mathrm{r}^{2}$ & $\mathrm{~F}$ & $\mathrm{p}$ & Variables with significant standardized Beta $(\beta, \mathrm{t}, \mathrm{p})$ \\
\hline \multicolumn{5}{|c|}{ Family \& Friends } \\
\hline Block 1 & 0.06 & & $<0.001$ & \\
\hline Block 2 & 0.14 & 8.05 & $<0.001$ & $\begin{array}{l}\text { Praise no. }(0.31 ; 4.13 ;<0.001) \text {; instrumental no. }(-.28 ;-3.72 ;<0.001) \text {; } \\
\text { instrumental spouse }(0.18 ; 3.38 ; 0.001) \text {; emotional satisfaction }(0.10 ; 1.95 \text {; } \\
0.052)\end{array}$ \\
\hline \multicolumn{5}{|c|}{ Religious Orientation } \\
\hline Block 1 & 0.06 & & $<0.001$ & \\
\hline Block 2 & 0.23 & 13.61 & $<0.001$ & $\begin{array}{l}\text { Instrumental spouse }(0.36 ; 8.16 ;<0.001) \text {; self-disclosure no. }(0.13 ; 2.12 \text {; } \\
0.035) \text {; loss no. }(-0.26 ;-3.28 ; 0.001) \text {; loss spouse }(0.24 ; 3.59 ;<0.001)\end{array}$ \\
\hline \multicolumn{5}{|c|}{ Job Satisfaction } \\
\hline & 0.14 & 9.16 & $<0.001$ & $\begin{array}{l}\text { Age }(\beta=-.41 ; \mathrm{t}=-3.80 ; \mathrm{p}>.001) ; \text { spouse age }(\beta=.49 ; \mathrm{t}=4.69 ; \mathrm{p}>.001) \\
\text { spouse education }(\beta=.14 ; \mathrm{t}=2.78 ; \mathrm{p}=.006) ; \text { spouse job }(\beta=-.13 ; \mathrm{t}= \\
-2.87 ; \mathrm{p}=.004) ; \text { praise satisfaction }(0.21 ; 4.11 ;<0.001) ; \text { self-disclosure no. } \\
(-0.09 ;-2.06 ; 0.040) \text {, instrumental spouse }(-0.10 ;-2.02 ; 0.044)\end{array}$ \\
\hline
\end{tabular}

Table $4 \mathrm{~b}$. Hierarchical multiple regressions with social support domain scores as independent and marital satisfaction domains as dependent variables controlling for socio-demographic variables (Block 1$)\left(1^{\text {st }}\right.$ block: method enter; $2^{\text {nd }}$ block: method stepwise) in males

\begin{tabular}{|c|c|c|c|c|}
\hline Independent & Adjusted $r^{2}$ & $\mathrm{~F}$ & $\mathrm{p}$ & Variables with significant standardized Beta $(\beta, \mathrm{t}, \mathrm{p})$ \\
\hline \multicolumn{5}{|c|}{ Personality Issues } \\
\hline Block 1 & 0.04 & & 0.058 & \\
\hline Block 2 & 0.31 & 6.90 & $<0.001$ & $\begin{array}{l}\text { Belongingness spouse }(0.35 ; 3.60 ;<0.001) \text {; emotional spouse }(0.21 \text {; } \\
2.15 ; 0.033) \text {; praise no. }(0.28 ; 2.27 ; 0.024) \text {; loss satisfaction }(0.17 \text {; } \\
2.37 ; 0.019) \text {; instrumental no. }(-0.36 ;-3.04 ; 0.003)\end{array}$ \\
\hline
\end{tabular}

\begin{tabular}{llll}
\hline \multicolumn{2}{l}{ Marital Communication } & & \\
Block 1 & 0.06 & & 0.027 \\
Block 2 & 0.42 & 10.76 & $<0.001$
\end{tabular}

Conflict Resolution

\begin{tabular}{|c|c|c|c|c|}
\hline Block 1 & 0.02 & & 0.171 & \\
\hline Block 2 & 0.31 & 7.49 & $<0.001$ & $\begin{array}{l}\text { Belongingness spouse }(0.53 ; 7.09 ;<0.001) \text {; praise no. }(0.28 ; 2.32 \text {; } \\
0.022) \text {; instrumental no. }(-0.42 ;-3.59 ;<0.001) \text {; self-disclosure no. } \\
(0.27 ; 3.46 ; 0.001)\end{array}$ \\
\hline
\end{tabular}

\section{Financial Management}

$\begin{array}{llll}\text { Block 1 } & 0.08 & & 0.006 \\ \text { Block 2 } & 0.34 & 7.42 & <0.001\end{array}$

Belongingness spouse $(0.54 ; 6.544 ;<0.001)$; emotional satisfaction $(0.33 ; 4.68 ;<0.001)$; loss satisfaction $(0.18 ; 2.75 ; 0.007)$; emotional no. $(-0.20 ;-2.78 ; 0.006)$; instrumental spouse $(-0.17 ;-1.98 ; 0.049)$

$(0.27 ; 3.46 ; 0.001)$

Belongingness spouse $(0.32 ; 3.31 ; 0.001)$; praise satisfaction $(0.22$; $2.54 ; 0.012)$; self-disclosure spouse $(-0.19 ; \quad-2.58 ; 0.011)$; self-disclosure satisfaction $(0.22 ; 2.91 ; 0.004)$; emotional spouse $(0.32 ; 2.97 ; 0.003)$; praise spouse $(-0.32 ;-3.02 ; 0.003)$

\begin{tabular}{|c|c|c|c|c|}
\hline \multicolumn{5}{|c|}{ Pleasure Activities } \\
\hline Block 1 & 0.12 & & $<0.001$ & \\
\hline Block 2 & 0.32 & 8.55 & $<0.001$ & $\begin{array}{l}\text { Belongingness spouse }(0.33 ; 4.337 ;<0.001) \text {; emotional satisfaction } \\
(0.30 ; 4.14 ;<0.001) \text {; instrumental no. }(-0.15 ;-2.03 ; 0.044)\end{array}$ \\
\hline \multicolumn{5}{|c|}{ Sexual Activities } \\
\hline Block 1 & 0.12 & & $<0.001$ & \\
\hline Block 2 & 0.43 & 12.00 & $<0.001$ & $\begin{array}{l}\text { Belongingness no. }(-0.44 ;-5.99 ;<0.001) ; \text { praise spouse }(0.28 ; 3.45 ; \\
0.001) \text {; self-disclosure spouse }(-0.19 ;-2.92 ; 0.004) \text {; belongingness } \\
\text { spouse }(0.32 ; 3.58 ;<0.001)\end{array}$ \\
\hline
\end{tabular}




\begin{tabular}{lllll}
\hline Independent & Adjusted $\mathrm{r}^{2}$ & $\mathrm{~F}$ & $\mathrm{p}$ & Variables with significant standardized Beta $(\beta, \mathrm{t}, \mathrm{p})$ \\
\hline Marriage \& & Children & & & \\
Block 1 & 0.20 & & $<0.001$ & \\
Block 2 & 0.57 & 14.10 & $<0.001$ & Belongingness satisfaction $(0.57 ; 5.180 ;<0.001) ;$ belongingness \\
& & & spouse $(0.33 ; 3.68 ;<0.001) ;$ instrumental satisfaction $(-0.30 ;-2.54 ;$ \\
& & & $0.013)$; emotional no. $(-0.28 ;-3.58 ; 0.001) ;$ \\
\hline
\end{tabular}

Family \& Friends

Block $1 \quad 0.06$

Block $2 \quad 0.41 \quad 10.06<0.001$
Belongingness spouse $(0.20 ; 2.07 ; 0.041)$; instrumental no. $(-0.45$; $-6.06 ;<0.001)$; belongingness satisfaction $(0.28 ; 3.47 ; 0.001)$; emotional spouse $(0.25 ; 2.72 ; 0.007)$; loss satisfaction $(0.16 ; 2.43$; $0.016)$

\begin{tabular}{lccl}
\multicolumn{2}{l}{ Religious } & \\
Block 1 & 0.11 & & 0.001 \\
Block 2 & 0.39 & 10.44 & $<0.001$
\end{tabular}

Praise satisfaction $(0.21 ; 2.80 ; 0.006)$; belongingness spouse $(0.40$; $5.59 ;<0.001)$; loss satisfaction $(0.28 ; 4.16 ;<0.001)$; instrumental no. $(-0.24 ;-3.27 ; 0.001)$

Job satisfaction $0.22 \quad 6.54<0.001 \quad$ Age $(\beta=-.39 ; \mathrm{t}=-2.12 ; \mathrm{p}=.036)$; education $(\beta=.54 ; \mathrm{t}=5.085 ; \mathrm{p}$ $<.001)$; belongingness spouse $(0.24 ; 3.22 ; 0.002)$; emotional no. $(0.24 ; 3.02 ; 0.001)$

\subsection{Associations between Job Satisfaction, Marital Satisfaction and Social Support}

When separating job satisfaction from the socio-demographic variables as a second block within these calculations, it additionally explained between $0 \%$ (women: in Pleasure Activities and Sexual Activities; men: Personality Issues and Conflict Resolution) and $3 \%$ of variance among the women in Family \& Friends and $5 \%$ in Marriage \& Children among the men when controlling for the impact of the various social-demographic variables in block 1 (findings not presented in a table). After inclusion of the various social support variables into the regression as a third block, job satisfaction kept its variance explaining power for marital satisfaction scales among the women for Personality issues $(\beta=.17 ; \mathrm{t}=4.32 ; \mathrm{p}>.001)$, Marital Communication $(\beta=.09 ; \mathrm{t}=2.26$; $\mathrm{p}=.024)$, Financial Management $(\beta=.09 ; \mathrm{t}=2.36 ; \mathrm{p}=.019)$, Family \& Friends $(\beta=.17 ; \mathrm{t}=3.67 ; \mathrm{p}>.001)$, and Religious Orientation $(\beta=.12 ; \mathrm{t}=2.67 ; \mathrm{p}=.008)$ as well as for Marriage \& Children $(\beta=.21 ; \mathrm{t}=2.70 ; \mathrm{p}$ $=.0008)$ and Family $\&$ Friends $(0.17 ; 2.48 ; 0.014)$ for men. However, its explanatory impact lost its significance when including the social support variables into the equation for scales Financial Management, Pleasure Activities, Sexual Activities, and Religious Orientations among men.

Fourteen percent of the variance in job satisfaction could be explained by the variation in socio-demographic variables and the various social support variables among the women and $22 \%$ among the men (see Table $4 a$, b).

\subsection{Prediction of Marital Satisfaction by Total Social Support (findings not presented in a table)}

When replacing the differentiated social support scores based on the situations of need for support by the three total social support scores (number of supporting persons, satisfaction with support, spouse support) within the regression equation, the variation in the variables in both blocks together explained between $11 \%$ (Family and Friends) and $36 \%$ (Personality Issues) for the women; and, between $18 \%$ (Family and Friends) and $26 \%$ (Marriage \& Children and Religious Orientation) in the men. Spouse support was the only significant variable of the three social support scores remaining as significantly explaining variance in the ENRICH scores among the women with percentages between $5 \%$ of Family \& Friends and $26 \%$ of Personality Issues. In the men's data, spouse support alone explained between $6 \%$ of variance in Marriage \& Children and $17 \%$ in Personality Issues and Conflict Resolution.

\section{Discussion}

The general aim of our investigation was to assess the relationship between social and spousal support and marital satisfaction in Iranian medical staff. Our findings confirmed previous results that men usually report higher marital satisfaction than do women (Jose \& Alfons, 2007; Ng, Loy, Gudmunson, \& Cheong, 2009) even though they did not differ on satisfaction with social support. Today, Iranian women are still the main responsible 
for the majority of household duties even if they have a job outside the family (Rafatjah, 2011). Therefore, women usually perceive more stress because of additional duties related to childcare and other household tasks (for more also see Rostami, Ghazinour, Nygren, \& Richter, 2013).

Results showed that although the total social support satisfaction and the total number of supporting people were not different between men and women; women were more often perceived as support providers for their husbands than men were for their wives. This finding corresponds to the "support-gap hypothesis" (Belle, 1982) which notions that women receive less support from their spouses than men receive from their spouses. This difference can also be explained by social and cultural expectations from women to be more supportive and providers of nurturance and support (Barbee et al., 1993; Schwarzer \& Gutierrez-Dona, 2005; Wood, 1994) and for men by the masculine role according to which men are assumed to behave more independently and self-reliant (Deaux \& Marianne, 1998). This social expectation guides women to seek and provide support more often and better than men. Based on an investigation among Iranian couples, Izadi and colleagues (2010) revealed that women expect their husbands to express their love and support both verbally and behaviorally. Iranian women expect their husband to be romantic and emotional; to remember their special occasions such as birthday or wedding anniversary; to express their love directly in words; and also to collaborate in household chores and child rearing. However, Iranian men prefer to express their feelings in rather indirect behavioral ways such as attempts of providing the family with a better economical or practical situation. This obvious discrepancy related to expectancies may cause Iranian women experiencing less spouse support than men. Because of the ways men support their wives do not match the women's expectancies, the women often feel that their husbands don't care about them as much as they wish and perceive inadequate and dissatisfactory support from their husbands. Another interpretation from an empowerment perspective could be that male respondents in our sample are more passive supportive whereas female respondents are more active in giving support.

Spouse support was a more important indicator of marital satisfaction for women than for men. Several studies have shown that the link between husband's support and marital satisfaction in women is stronger than the link between wives' support and marital satisfaction in men (Acitelli \& Antonucci, 1994; Julien \& Markman, 1991). Also other studies showed that some husbands' support skills (e.g., relationship awareness, expressiveness, intimacy, maturity) are more predictive of relationship and life satisfaction in women than in men (Acitelli \& Antonucci, 1994; Lamke, 1989; Murstein \& Williams, 1985; White, Speisman, Jackson, Bartis, \& Costos, 1986). Indeed, findings showed spouse support is more important than social support from other resources to explain marital satisfaction. Support from partner is uniquely beneficial. In other words, inadequate spousal support isn't compensated by support from other sources (Coyne \& Delongis, 1986; DeLongis et al., 2004). When couples perceive their spouse as the main resource of support, the family cohesion and the emotional bonds between couples become stronger and this can lead to the higher marital satisfaction.

Furthermore, support in situations of need for instrumental support or self-disclosure support from husbands among women and in situations of need for belongingness support from wives among men were most predictive related to marital satisfaction. Women tend to be more self-disclosing than man; and they also tend more positively to assess their marital satisfaction by their self-disclosure about personal facts, feeling and communication (Peplau \& Gordon, 1985). Thus, spouse support in self-disclosure can be a more important factor related to women's marital satisfaction than men's. Monadi's study (2004) among Iranian couples in Tehran indicated that disclosing had an important effect on marital satisfaction especially in women. Women were more satisfied when their husbands listened and cared about their disclosing. They like to talk about the problems and stressful events of life and expect their husbands to care about that even if they can't solve the problem.

Also, as Mickelson and colleagues (2006) reported, instrumental support in addition to emotional support predicted marital satisfaction in women with an egalitarian gender role belief. Since the women of the current study were an educated and socially active group, it seems that the spouse's instrumental support, for example, helping in household task and child rearing, is highly expected. Although in many of todays Iranian families women work outside, men are still the main responsible person for providing with the expenses of the family. Izadi and colleagues (2010) results showed that even educated and employed working Iranian women expected their husbands to provide the family expenses to cover their and their children's needs. Furthermore regarding house chores and child rearing, all women expected cooperation from their husbands. Since the women are still supposed to be responsible for household and children duty in Iranian families, the expectation of cooperation in these subjects could be a clash of expectations between couples in modern Iranian families. As our findings showed instrumental support is predicted as effective in many domains of marital satisfaction for example "financial management", "marriage and children", "communication", "conflict resolution" and "personality issues". It seems that women expect men to support them when they need consultation about their problems, help 
for family and children duties and even support as financial source of family.

Furthermore, support in situations of need for belongingness from wives among men was related to all domains of marital satisfaction. It means knowing that he was "an important part of his wife's life" and his wife "cared about him regardless of what is happening to him" and "loved him deeply", could improve marital satisfaction in all aspects especially in "marriage and children" domain. Being convinced from the unconditional love of their wives and having the feeling that the wife has a deep sense of belongingness are important factors in marital satisfaction in men in this sample. Based on religion and cultural principals, women are still taught to be obedient, patient and supporting to her husband in Iran. Being the breadwinner of the family gives men higher authority in the family. About $65 \%$ of the women in our study were educated, employed $(60 \%)$, and economically independent. In this type of family with decreased men's economical authority and women's financial dependency, the emotional belonging of wives means more for men. In another words, the men feel more power and satisfaction when they feel that they have their wives' love, concern and care.

The higher explanatory effect of job satisfaction in men could also be explained by the importance of a job for men compare to women. Men are supposed to be the main breadwinner in an Iranian family; and having a job is more important in men's life compared to women's taking them culturally and religiously determined role of men in Iranian families into account. The work domain is a greater source of problems for men than the family domain which is the greater source of conflicts for women. Therefore, the negative effect of job conflicts on the family domain in men is higher than among women (Karimi, 2009; Lambert, 1990; Posig \& Kickul, 2004). Furthermore, the findings showed that social support could decrease the explanatory impact of job satisfaction on many marital satisfaction scales. The findings based on the family stress theory, as described by Hill (2005), confirm the importance of the moderating role of social support in effect of job satisfaction on marital satisfaction. Furthermore, Karimi and Nouri (2009) found that the family conflict because of a job has a negative relationship with perceived social support in a study in Iranian men.

Additionally, the explanatory impact of socio-demographic variables and social support on the variance of job satisfaction also confirmed the findings of other studies in Iran and western countries (Harris, Winskowski, \& Engdahl, 2007; Veissi, Atefvahid, \& Rezaee, 2000) and revealed that social support protects people from potentially negative influences of stressful events like the stress-buffer theory posits.

According to the results, cultural gender expectations, family stress (such as conflicts between couples, household and childrearing responsibilities), socio-demographic characteristics and job stress related to work as medical staff as stressors on one the hand and social and spousal support and socio-demographic characteristics as resources and support on the other hand determine perceived family stress and job stress by couples which consequently determined the level of perceived marital satisfaction and job satisfaction.

The present study had several limitations. Marital satisfaction and social support were assessed by only one partner of each couple, which made impossible comparisons within couples. Investigating dyadic marital satisfaction and social support would provide more detailed information especially about spouses support and its possible causality. The cross-sectional study design restricted the interpretation of the relationships between marital satisfaction and other factors. However, despite the limitations mentioned above, we believe that our findings should be considered by family counselors, psychologists and social workers and health policy makers especially at workplaces since there is a lack of knowledge about social support and marital satisfaction in Iran.

\section{References}

Acitelli, L. K. (1996). The neglected links between marital support and marital satisfaction. In G. R. Pierce, B. R. Sarason \& I. G. Sarason (Eds.), Handbook of social support and the family (pp. 33-104). New York: Plenum Press.

Acitelli, L. K., \& Antonucci, T. C. (1994). Gender differences in the link between marital support and satisfaction in older couples. Journal of Personality and Social Psychology, 67(4), 688-698. $\mathrm{http}: / / \mathrm{dx}$.doi.org/10.1037//0022-3514.67.4.688

Adeb-Saeedi, J. (2002). Stress among emergency nurses. Australian Emergency Nursing Journal, 5(2), 19-24.

Ardekani, Z., Kakooei, H., Ayattollahi, S., Choobineh, A., \& Seraji, G. (2008). Prevalence of mental disorders among shift work hospital nurses in Shiraz, Iran. Pakistan Journal of Biological Sciences, 11(12), 1605-1609.

Ashton, W. A., \& Fuehrer, A. (1993). Effects of gender and gender-role identification of participants and type of social support resource on support seeking. Sex Roles, 28(7-8), 461-476. http://dx.doi.org/10.1007/bf00289608 
Aycan, Z., \& Eskin, M. (2005). Relative contributions of childcare, spousal support, and organizational support in reducing work-family conflict for men and women: The case of Turkey. Sex Roles, 53(7-8), 453-471. http://dx.doi.org/10.1007/s11199-005-7134-8

Barbee, A. P., Cunningham, M. R., Winstead, B. A., Derlega, V. J., Gulley, M. R., Yankeelov, P. A., \& Druen, P. B. (1993). Effects od gender-role expectations on the social support process. Journal of Social Issues, 49(3), $175-190$

Beach, S. R. H., Martin, J. K., Blum, T. C., \& Roman, P. M. (1993). Effects of marital and coworker relationships on negative affect: Testing the central role of marriage. American Journal of Family Therapy, 21(4), 313-323. http://dx.doi.org/10.1080/01926189308251002

Belle, D. (1982). The stress of caring: Women as providers of social support. In L. Goldber \& S. Bresnitz (Eds.), Handbook of stress: Theoretical and clinical aspects (pp. 496-505). New York: Free Press.

Bellman, S., Forster, N., Still, L., \& Cooper, C. L. (2003). Gender differences in the use of social support as a moderator of occupational stress. Stress and Health, 19(1), 45-58. http://dx.doi.org/10.1002/smi.954

Bodenmann, G. (2000). Stress und coping beipaaren [stress and coping in couples]. Göttingen: Hogrefe.

Button, L. (2008). Effect of social support and coping strategies on the relationship between health care related occupational stress and health. Journal of Research in Nursing, 13(6), 498-524.

Chi, P. L., Tsang, S. K. M., Chan, K. S., Xiang, X. P., Yip, P. S. F., Cheung, Y. T., \& Zhang, X. L. (2011). Marital satisfaction of Chinese under stress: Moderating effects of personal control and social support. Asian Journal of Social Psychology, 14(1), 15-25. http://dx.doi.org/10.1111/j.1467-839X.2010.01322.x

Cohen, S. (2004). Social relationships and health. American Psychologist, 59(8), 676-684. $\mathrm{http}: / / \mathrm{dx}$.doi.org/10.1037/0003-066x.59.8.676

Cory, C. W. (2007). The relationship between professional burnout and marital satisfaction. Capella University, Minnesota.

Coyne, J. C., \& Delongis, A. (1986). Going beyond social support: The role of social relationships in adaptation. $\begin{array}{lllll}\text { Journal of Consulting and Clinical Psychology, 54(4), 454-460. } & \text {. }\end{array}$ http://dx.doi.org/10.1037/0022-006x.54.4.454

Deaux, K., \& Marianne, L. (1998). Gender. In D. T. Gilbert, S. T. Fiske \& G. Lindzey (Eds.), The handbook of social psychology. New York: McGraw-Hill.

DeLongis, A., Capreol, M., Holtzman, S., O'Brien, T., \& Campbell, J. (2004). Social support and social strain among husbands and wives: A multilevel analysis. Journal of Family Psychology, 18(3), 470-479. http://dx.doi.org/10.1037/0893-3200.18.3.470

Demaray, M. K., \& Malecki, C. K. (2002). Critical levels of perceived social support associated with student adjustment. School Psychology Quarterly, 17(3), 213-241.

Fowers, B. J., \& Olson, D. H. (1989). ENRICH marital inventory: A discriminant validity and cross-validation assessment. Journal of Marital and Family Therapy, 15(1), 65-79. http://dx.doi.org/10.1111/j.1752-0606.1989.tb00777.x

Gottlieb, B. H. (1994). Social support. In A. L. Weber \& J. H. Harvey (Eds.), Perspectives on close relationships (pp. 307-324). Boston: Allyn \& Bacon.

Hamaideh, S. (2012). Occupational stress, social support, and quality of life among Jordanian mental health nurses. Issues in Mental Health Nursing, 33(1), 15-23.

Harris, J. I., Winskowski, A. M., \& Engdahl, B. E. (2007). Types of workplace social support in the prediction of job satisfaction. Career Development Quarterly, 56(2), 150-156.

Hill, E. J. (2005). Work-family facilitation and conflict, working fathers and mothers, work-family stressors and support. Journal of Family Issues, 26(6), 793-819. http://dx.doi.org/10.1177/0192513x05277542

Hill, R. (1958). Social Stresses on The Family. Generic Features Of Families Under Stress. Social Casework, 39(2-3), 139-150.

Hochschild, A. (1997). The time bind: When work becomes home and home becomes work. New York: Holt.

House, J. S. (1981). Work stress and social support. Menlo Park, CA: Addison-Wesley.

Hughes, D., Galinsky, E., \& Morris, A. (1992). The effects of job characteristics on marital quality: Specifying 
linking mechanisms. Journal of Marriage and the Family, 54(1), 31-42. http://dx.doi.org/10.2307/353273

Hughes, D. L., \& Galinsky, E. (1994). Gender, job and family conditions, and psychological symptoms. Psychology of Women Quarterly, 18(2), 251-270. http://dx.doi.org/10.1111/j.1471-6402.1994.tb00454.x

Izadia, A., Reyhan Ebrahimi, H. R., \& Zilaiec, F. (2010). Husband-wife's expectation of opposite-sex spouse and the construction of gender identity. International Journal of Innovative Interdisciplinary Research, 2, 101-106.

Jose, O., \& Alfons, V. (2007). Do demographics affect marital satisfaction? Journal of Sex \& Marital Therapy, 33(1), 73-85. http://dx.doi.org/10.1080/00926230600998573

Julien, D., \& Markman, H. J. (1991). Social support and social networks as determinants of individual and marital outcomes. Journal of Social and Personal Relationships, 8(4), 549-568. http://dx.doi.org/10.1177/026540759184006

Karimi, L. (2009). Do female and male employees in Iran experience similar work-family interference, job, and life satisfaction? Journal of Family Issues, 30(1), 124-142. http://dx.doi.org/10.1177/0192513x08324973

Karimi, L., \& Nouri, A. (2009). Do work demands and resources predict work-to-family conflict and facilitation? A study of Iranian male employees. Journal of Family and Economic Issues, 30, 193-202.

Klauer, T., \& Winkeler, M. (2002). Gender, mental health status, and social support during a stressful event. In G. Weidner, M. Kopp \& M. Kristenson (Eds.), Heart disease: Environment, stress, and gender (Vol. 327, pp. 223-236). Amsterdam: IOS Press.

Laireiter, A., \& Baumann, U. (1992). Network structures and support functions: Theoretical and empirical analyses. In H. O. F. Veiel \& U. Baumann (Eds.), The meaning and measurement of social support (pp. 33-55). Washington, DC: Hemisphere.

Lambert, S. J. (1990). Processes linking work and family: A critical review and research agenda. Human Relations, 43(3), 239-257. http://dx.doi.org/10.1177/001872679004300303

Lamke, L. K. (1989). Marital adjustment amoung rural couples: The role of expressiveness. Sex Roles, 21(9-10), 579-590. http://dx.doi.org/10.1007/bf00289172

Lieberman, M. A. (1982). The effects of social supports on response to stress. In L. Goldberger \& S. Breznitz (Eds.), Handbook of stress: Theoretical and clinical aspects (pp. 764-784). New York: Free Press.

Mauno, S., \& Kinnunen, U. (1999). The effects of job stressors ton marital satisfaction in Finnish dual-earner $\begin{array}{llll}\text { couples. Journal of } & \text { Organizational Behavior, 20(6), }\end{array}$ http://dx.doi.org/10.1002/(sici)1099-1379(199911)20:6<879::aid-job982>3.0.co;2-2

McCubbin, H. I., \& Patterson, J. M. (1983). The family stress process: The double ABCX model of family adjustment and adaptation. In H. I. McCubbin, M. Sussman \& J. M. Patterson (Eds.), Social stress and the family: Advances and developments in family stress theory and research (pp. 7-37). New York: Haworth.

McFarlane, A. H., Neale, K. A., Norman, G. R., Roy, R. G., \& Streiner, D. L. (1981). Methodological issues in developing a scale to measure social support. Schizophrenia Bulletin, 7(1), 90-100.

Mickelson, K. D., Claffey, S. T., \& Williams, S. L. (2006). The moderating role of gender and gender role attitudes on the link between spousal support and marital quality. Sex Roles, 55(1-2), 73-82. http://dx.doi.org/10.1007/s11199-006-9061-8

Monadi, M. (2004). Tasire tasavorat va ta-aarife moshabehe zojeyn dar rezayat az zendegiye zanashooi az didgahe zanan. [Effect of similarity of couples' perceptions and definitions on women's marital satisfaction]. Faslnameye Motaleate Ejtemai Ravanshenakhtiye Zanan, 2(4).

Mosadeghrad, A. M., Ferlie, E., \& Rosenberg, D. (2011). A study of relationship between job stress, quality of working life and turnover intention among hospital employees. Health Services Management Research, 24(4), 170-181.

Murstein, B. I., \& Williams, P. D. (1985). Assortative matching for sex-role and marriage adjustment. Personality and Individual Differences, 6(2), 195-201. http://dx.doi.org/10.1016/0191-8869(85)90109-6

Nasseh, M., Ghazinour, M., Joghataei, M., Nojomi, M., \& Richter, J. (2011). Goneye farsie porseshnameye hemayate ejtemai. [A Persian version of the Social Support Questionnaire (SSQ)]. Faslnameye Refahe Ejtemai, 11(41), 251-266.

Neff, L. A., \& Karney, B. R. (2004). How does context affect intimate relationships? Linking external stress and 
cognitive processes within marriage. Personality and Social Psychology Bulletin, 30(2), 134-148. http://dx.doi.org/10.1177/0146167203255984

Neff, L. A., \& Karney, B. R. (2005). Gender differences in social support: A question of skill or responsiveness? Journal of Personality and Social Psychology, 88(1), 79-90. http://dx.doi.org/10.1037/0022-3514.88.1.79

Ng, K. M., Loy, J. T. C., Gudmunson, C. G., \& Cheong, W. (2009). Gender differences in marital and life satisfaction among Chinese Malaysians. Sex Roles, 60(1-2), 33-43. http://dx.doi.org/10.1007/s11199-008-9503-6

Olson, D., Fournier, D., \& Druckman, J. (1983). PREPARE/ENRICH counselor's manual. Minneapolis, MN: PREPARE/ENRICH. Inc.

Pasch, L. A., \& Bradbury, T. N. (1998). Social support, conflict, and the development of marital dysfunction. Journal of Consulting and Clinical Psychology, 66(2), 219-230. http://dx.doi.org/10.1037/0022-006x.66.2.219

Patterson, J. M. (2002). Integrating family resilience and family stress theory. Journal of Marriage and Family, 64(2), 349-360. http://dx.doi.org/10.1111/j.1741-3737.2002.00349.x

Peplau, L. A., \& Gordon, S. L. (1985). Women and men in love: Sex differences in close heterosexual relationships In V. E. O'Leary, R. K. Unger \& B. S. Wallston (Eds.), Women, sex, and social psychology (pp. 257-291). Hillsdale, NJ: Erlbaum.

Posig, M., \& Kickul, J. (2004). Work-role expectations and work family conflict: gender differences in emotional exhaustion. Women in Management Review, 19(7), 373-386.

Rafatjah, M. (2011). Changing gender stereotypes in Iran. International Journal of Women's Research, 1(1), 61-75.

Rasooli, M. (2001). Investigation of relationship between career stress with marital satisfaction and mental health in police officers (Unpublished master's thesis).Tehran University, Tehran.

Reevy, G. (2007). Sex-related differences in the social support-stress relationship. In A. Monat (Ed.), The Praeger Handbook on Stress and Coping (pp. 349-361). Westport, CT: Praeger Publishers/Greenwood Publishing Group.

Roberts, N. A., \& Levenson, R. W. (2001). The remains of the workday: Impact of job stress and exhaustion on marital interaction in police couples. Journal of Marriage and Family, 63(4), 1052-1067. http://dx.doi.org/10.1111/j.1741-3737.2001.01052.x

Rogers, S. J., \& May, D. C. (2003). Spillover between marital quality and job satisfaction: Long-term patterns and gender differences. Journal of Marriage and Family, 65(2), 482-495. http://dx.doi.org/10.1111/j.1741-3737.2003.00482.x

Rostami, A., Ghazinour, M., Nygren, L., \& Richter, J. (2013) (In press). Marital satisfaction with a special focus on gender differences in medical staff in Tehran-Iran. Journal of Family Issues.

Sarason, I. G., Levine, H. M., Basham, R. B., \& Sarason, B. R. (1983). Assessing social support: The social support questionnaire. Journal of Personality and Social Psychology, 44(1), 127-139. http://dx.doi.org/10.1037//0022-3514.44.1.127

Schwarzer, R., \& Gutierrez-Dona, B. (2005). More spousal support for men than for women: A comparison of sources and types of support. Sex Roles, 52(7-8), 523-532. http://dx.doi.org/10.1007/s11199-005-3718-6

Schwarzer, R., \& Leppin, A. (1991). Social support and health: A theoretical and empirical overview. Journal of Social and Personal Relationships, 8(1), 99-127. http://dx.doi.org/10.1177/0265407591081005

Serafini, B. J. (2010). Work family preferences, behavior, and marital satisfaction in an age of egalitarianism. Paper presented at the Annual meeting program of population association of America, Texas. http://paa2010.princeton.edu/papers/101827

Soleimanian, A. (1994). Survey effect of illogical thinking (cognitive theory) in marital satisfaction. Tarbiat Moalem University, Tehran.

Story, L. B., \& Bradbury, T. N. (2004). Understanding marriage and stress: Essential questions and challenges. Clinical Psychology Review, 23(8), 1139-1162. http://dx.doi.org/10.1016/j.cpr.2003.10.002

Su, J. A., Weng, H. H., Tsang, H. Y., \& Wu, J. L. (2009). Mental health and quality of life among doctors, nurses and other hospital staff. Stress and Health, 25(5), 423-430. http://dx.doi.org/10.1002/smi.1261 
Vanfossen, B. E. (1981). Sex-differences in the mental-health effects of spouse support and equity. Journal of Health and Social Behavior, 22(2), 130-143. http://dx.doi.org/10.2307/2136289

Veissi, M., Atefvahid, M., \& Rezaee, M. (2000). Tasire strese shoghli bar khoshnoudiye shoghli va salamate ravan: Asare tadilkonnadehe sarsakhti va hemayate ejtemai. [Job stress, job satisfaction and mental health: The balancing effects of personal hardiness and social support network factors]. Majalehe Ravanpezeshki Va Ravanshenasiye Baliniye Iran, 6(2), 70-79.

Vinokur, A. D., \& Vinokur-Kaplan, D. (1990). In sickness and in health: Patterns of social support and undermining in older married couples. Journal of Aging and Health, 2, 215-241.

Walen, H. R., \& Lachman, M. E. (2000). Social support and strain from partner, family, and friends: Costs and benefits for men and women in adulthood. Journal of Social and Personal Relationships, 17(1), 5-30. http://dx.doi.org/10.1177/0265407500171001

White, K. M., Speisman, J. C., Jackson, D., Bartis, S., \& Costos, D. (1986). Intimacy maturity ans its correlates in young married-couples. Journal of Personality and Social Psychology, 50(1), 152-162. http://dx.doi.org/10.1037/0022-3514.50.1.152

Wood, J. T. (1994). Who cares? Women, care, and culture. Carbondale: Southern Illinois University Press.

Wu, S. Y., Li, H. Y., Wang, X. R., Yang, S. J., \& Qiu, H. (2011). A Comparison of the effect of work stress on burnout and quality of life between female nurses and female doctors. Archives of Environmental \& Occupational Health, 66(4), 193-200. http://dx.doi.org/10.1080/19338244.2010.539639 